\title{
Evaluation of Selected Raspberry and Strawberry Cultivars in Southern Idaho
}

\author{
Jo Ann Robbins
}

ADDITIONAL INDEX wORDs. fruit yield, fruit weight, raspberry production, strawberry production

Summary. The growth, yield, and berry weight of nine June-bearing strawberry (Fragaria xananassa) cultivars ('Allstar', 'Cavendish', 'Honeoye', 'Jewel', 'Kent', 'Mesabi', 'Mira', 'Northeaster', and 'Winona') and six floricane fruiting (summerbearing) raspberry ( $R$ ubus idaeus) cultivars ('Algonquin', 'K-81-6', 'Lauren', 'Nova', 'Qualicum', and 'Reveille') grown in southern Idaho were compared. 'Cavendish', 'Mesabi,' and 'Winona' established quickly and maintained their spring vigor. Strawberry cultivars grew well during the summer but some cultivars had low spring vigor ratings. The most reliable yielding cultivars were 'Cavendish' and 'Mesabi' in spite of spring frosts, which damaged blossoms. 'Mesabi' yielded best during a season where plants suffered spring freeze injury. Only 'Mesabi' yielded above 6 tons/acre (2001). Spring freezing and relatively low yields are limiting factors in strawberry production in southern Idaho. Berry weight averaged 5.5 to $8.8 \mathrm{~g}$ in the second year of the study and may be too small for consumer acceptance and other commercial competition. 'Cavendish' and 'Mesabi' fruited earliest and 'Honeoye' and 'Winona' were latest. Raspberry shoot and cane growth was strong in all years. Over the course of the study, highest yielding in 2001 was 'Nova' (7.65 tons/acre) and in 2002 'K-81-6' (10.4 tons/acre). In the second year of harvest (2002), all cultivars produced greater than the projected commercial production requirement of 3 tons/acre. Raspberry bloom occurred after the spring frosts. Berry weight was largest in ' $K$ 81-6' (3.3 and $2.5 \mathrm{~g}$ in 2001 and 2002, respectively) and smallest in 'Algonquin' ( 1.8 and $1.5 \mathrm{~g}$ in 2001 and 2002 , respectively). Early fruiting cultivars were 'Nova' and 'Reveille'.

S outhern Idaho is experiencing increasing demand for local niche products. Small farmers and traditional agricultural producers seeking to diversify need reliable alternate crop information and are interested in small fruit production. Local marketing outlets include you-pick operations, farmers' markets, and farm stands. Strawberries and raspberries are both successful in home gardens in the area; however, there is little commercial production. No strawberry or raspberry cultivar trials have been done in southern Idaho using newer cultivars. Representative yield data can determine if commercial production would be profitable. This study site, just south of Ketchum, Idaho, is representative of southern Idaho USDA hardiness zone 4 growing conditions. It has a short season of 90 to 100 $\mathrm{d}$, cold winter nights with 0 to

$\overline{\text { Professor and Extension Educator, University }}$ of Idaho, Jerome County, 600 2nd Avenue West, Jerome, ID 83338.

Acknowledgments. Cooperators: Sawtooth Botanic Garden, PO Box 1168, Ketchum, Idaho 83340 and Idaho Master Gardener volunteers. Project support: Northwest Center for Small Fruits Research.
$-30{ }^{\circ} \mathrm{F}$, and days of 10 to $35^{\circ} \mathrm{F}$; warm, dry summer days of 75 to $90^{\circ} \mathrm{F}$, with cool nights of 40 to $60^{\circ} \mathrm{F}$.

According to enterprise budgets developed by Oregon State University (Cros and Strik, 1991; Turner et al., 1993), strawberries at $\$ 0.40 / 1 \mathrm{~b}$ must yield 6 tons/acre to break even with all costs. Raspberries, at $\$ 0.64 / \mathrm{lb}$, break even at 3 tons/acre with machine harvesting. The purpose of this study was to determine if southern Idaho production might be economically feasible using the cultivars in the trials.

\section{Materials and methods}

Plots were planted on 26 May 1999. Nine June-bearing strawberry

\begin{tabular}{|c|c|c|c|}
\hline \multicolumn{4}{|l|}{ Units } \\
\hline \multicolumn{4}{|l|}{$\begin{array}{l}\text { U.S. to SI, } \\
\text { multiply by }\end{array}$} \\
\hline \multicolumn{4}{|l|}{0.3048} \\
\hline 0.0929 & $\mathrm{ft}^{2}$ & $\mathrm{~m}^{2}$ & 10.7639 \\
\hline 2.5400 & inch(es) & $\mathrm{cm}$ & 0.3937 \\
\hline 0.4536 & $\mathrm{lb}$ & $\mathrm{kg}$ & 2.2046 \\
\hline 1.1209 & $\mathrm{lb} / \mathrm{acre}$ & $\mathrm{kg} \cdot \mathrm{ha}^{-1}$ & 0.8922 \\
\hline \multirow{3}{*}{$\begin{array}{l}28.3495 \\
2.2417 \\
\left({ }^{\circ} \mathrm{F}-32\right) \div 1.8\end{array}$} & $\mathrm{OZ}$ & $\mathrm{g}$ & 0.0353 \\
\hline & ton/acre & Mg.ha ${ }^{-1}$ & 0.4461 \\
\hline & ${ }^{\circ} \mathrm{F}$ & ${ }^{\circ} \mathrm{C}$ & $\left(1.8 \times{ }^{\circ} \mathrm{C}\right)+32$ \\
\hline
\end{tabular}


and six floricane fruiting (summerbearing) raspberry cultivars were randomized within three replications. Chosen cultivars were based on plant nursery recommendations of readily available high fruit quality cultivars likely to do well in the study area. All plants were obtained from Nourse Farms (South Deerfield, Mass.) except for 'Qualicum' raspberry (Spooner Farms, Puyallup, Wash.), and 'Algonquin' raspberry (Indiana Berry and Plant Co., Huntingburg, Ind.). Rows were $15 \mathrm{ft}$ long. In Fall 2001, strawberry plots were shortened to $10 \mathrm{ft}$. Strawberry cultivars included 'Allstar', 'Cavendish', 'Honeoye', 'Jewel', 'Kent', 'Mesabi', 'Mira', 'Northeaster', and 'Winona'. Raspberry cultivars were 'Algonquin', 'K-81-6', 'Lauren', 'Nova', 'Qualicum', and 'Reveille'. Spacing of raspberries was $3 \mathrm{ft}$ between plants in the row (five plants per replication) with rows $4 \mathrm{ft}$ apart (3630 plants/acre). Canes were thinned yearly with 2 to 4 inches between fruiting canes. All canes were restricted to a 2 -ft-wide area down the row. Fruiting canes were tied to a post and twine trellis system each spring. In row spacing of strawberries was 18 inches (10 plants per replication) with rows $3 \mathrm{ft}$ apart (9680 plants/acre). Matted rows approximately $2 \mathrm{ft}$ wide were maintained with a thinning and renovation following harvest each year.

Plots were drip irrigated as needed beginning 26 May 1999. The study site was organically managed, so plants were fertilized with fish fertilizer pellets [7N-3.1P-1.7K (Bio-Fish All Purpose Fertilizer; Down to Earth Distributors, Eugene, Ore.)]. Strawberries were fertilized after the final harvest (early August) with $50 \mathrm{lb} /$ acre of N. Raspberries were fertilized in a split application at full leaf (late May to early June) and fruit set (late June to early July) with $70 \mathrm{lb} /$ acre of N. Plots were kept weed free with bark, with additional annual straw mulch in the strawberries, and with hoeing and shallow rotovating. Strawberries were covered each year with straw for winter protection from October to early November through mid-April to early May. Each year, 2 to $4 \mathrm{ft}$ of snow covered the planting from early December through mid-April.

No disease or insect control was needed during the 4 years of the study.

Raspberries were supported by a post and twine trellis and pruned and trained in early to mid-May. Due to cold temperatures and a lack of honeybees (Apis mellifera) during raspberry bloom, Class $\mathrm{C}$ mini-hives of bumblebees (Bombus terrestis) each sufficient to cover 3000 to $4000 \mathrm{ft}^{2}$ and effective for 4 to 5 weeks were placed in the raspberries in mid-June for pollination (Biobest Canada, Leamington, Ont., Canada). One colony was purchased in 2002 and two were used in 2003.

In 1999 mule deer (Odocileus hemionus) browsing was noted on the larger strawberry leaves beginning in mid-August. This became more severe in September. The tips of the new raspberry canes were eaten in September by mule deer. On 29 Sept. 1999, a deer repellent [active ingredients ammonium salts of C18 fatty acids (Hinder; Pace International, LP, Kirkland, Wash.)] was applied to the plots. This reduced further damage. During the winter, mule deer continued to feed on the tips of the raspberry canes above the snow. As the planting grew stronger and the floricanes were stouter, winterfeeding by mule deer became less of a problem. Beginning in Aug. 2000, and continuing August through October annually, Garden Scarecrows (Contech
Electronics, Saanichton, B.C., Canada) controlled mule deer damage. These motion-detecting sprinklers direct an impulse of water toward movement and were effective each year in frightening away mule deer. In 2000, Hinder deer repellent was applied about every 14 $\mathrm{d}$ to the raspberry plants.

Data collected included subjective spring and fall vigor ratings in strawberries, fall primocane height in raspberries, and yield and average berry weight in both crops. Data were analyzed using SAS (SAS Institute, Cary, N.C.) PROC GLM.

\section{Results and discussion}

1999 STRAWBERRIES AND RASPBERRIES. 'Northeaster' strawberry and 'Lauren' raspberry were almost completely replanted on 9 June 1999 due to poor establishment of original plants. Approximately 10 other plants of various cultivars were replanted in early July. By late July all plants were healthy and strong except for 'Mira' strawberry and 'Lauren' raspberry, whose plants were smaller and displayed sparse foliage (data not shown).

2000-02 Strawberries. 'Cavendish', 'Mesabi', and 'Winona' established quickly and grew thick and strong over the study period (Table 1). All cultivars grew well during the summer, forming matted rows and rating high in fall vigor. By spring 'Allstar' and 'Northeaster' had low vigor ratings.

Below-freezing temperatures were experienced in May and June each year. Bloom began each year in mid-May. Unprotected flowers were damaged at $27^{\circ} \mathrm{F}$ on 31 May 2000 . Plants protected with floating row cover were damaged by two successive freezing nights late in bloom when, in 2001 , temperatures were 31 and $30^{\circ} \mathrm{F}$

Table 1. The 2000-02 average spring and fall plant vigor ratings of nine strawberry cultivars in a Ketchum, Idaho, planting established in May 1999.

\begin{tabular}{|c|c|c|c|c|c|c|c|c|}
\hline \multirow[b]{2}{*}{ Cultivar } & \multicolumn{4}{|c|}{ Avg spring vigor ${ }^{\mathrm{z}}$} & \multicolumn{4}{|c|}{ Avg fall vigor } \\
\hline & 15 May 2000 & 30 May 2001 & 31 May 2002 & 3-yr avg & 30 Aug. 2000 & 30 Aug. 2001 & 4 Oct. 2002 & 3-yr avg \\
\hline Allstar & 1.0 & 5.3 & 2.7 & 3.0 & 6.7 & 7.0 & 6.0 & 6.6 \\
\hline Honeoye & 4.7 & 7.0 & 4.7 & 5.5 & 7.7 & 7.7 & 6.3 & 7.2 \\
\hline Jewel & 4.3 & 7.3 & 5.3 & 5.6 & 8.0 & 8.3 & 6.7 & 7.7 \\
\hline Kent & 5.3 & 7.0 & 4.7 & 5.7 & 7.3 & 7.8 & 6.7 & 7.3 \\
\hline Northeaster & 3.0 & 5.3 & 4.3 & 4.2 & 7.7 & 7.3 & 6.0 & 7.0 \\
\hline Winona & 5.3 & 7.0 & 5.3 & 5.9 & 7.0 & 8.3 & 6.0 & 7.1 \\
\hline
\end{tabular}

${ }^{2}$ Vigor scale: 1 = barely alive; 5 = weak, but acceptable, growth; $10=$ growing extremely well. 
on 13 and 14 June, respectively. No damage occurred to protected plants earlier in the season at $28^{\circ} \mathrm{F}$ on 4 and 5 June 2001 and at $32^{\circ} \mathrm{F}$ on 9 June 2000.

In 2002, six successive nights of below freezing temperatures $(25,16$, $22,29,29$, and $31^{\circ} \mathrm{F}$ on $6,7,8,9$, 10 , and 11 May, respectively) severely damaged unprotected plants. Crowns can be damaged by temperatures below $22^{\circ} \mathrm{F}$ (Strik, 2002). When plants were observed on 14 May, the new foliage, unmulched on 4 May, was totally frozen. However, the crowns looked undamaged. This freezing accounts for the lower spring vigor ratings in all cultivars in 2002 when compared to 2001 (Table 1). Plant vigor in the fall was lower in 2002 than at the similar time in previous years, especially in 'Cavendish', 'Jewel', and 'Winona', indicating these cultivars may recover from spring plant freezing more slowly.

In 2000, 'Cavendish' and in 2001 and 2002 'Mesabi' outyielded all other cultivars by almost double or more (Table 2). However, 'Cavendish' and 'Mesabi' yielded 7.6 and 12 tons/acre, respectively, in a cultivar trial in westcentral Minnesota (D.K.Wildung, unpublished data). This indicates that yields in this study are comparatively low.

In 2002 strawberry yields were much lower than in the previous 3 years due to spring freeze damage. Only 'Mesabi' yielded above 1 ton/acre, which was significantly more than all other cultivars. Berry yields in 2002 were extremely variable within each cultivar, and affected the ability to determine significant differences.

Table 2. The 2000-02 yields of nine strawberry cultivars in a Ketchum, Idaho, planting established in May 1999.

\begin{tabular}{llll}
\hline & \multicolumn{3}{c}{ Yield (tons/acre) ${ }^{\mathrm{z}}$} \\
\cline { 2 - 4 } Cultivar & $\mathbf{2 0 0 0}$ & $\mathbf{2 0 0 1}$ & $\mathbf{2 0 0 2}$ \\
\hline Allstar & $0.09 \mathrm{c}$ & $0.79 \mathrm{de}$ & $0.07 \mathrm{c}$ \\
Cavendish & $1.33 \mathrm{a}$ & $3.61 \mathrm{~b}$ & $0.30 \mathrm{bc}$ \\
Honeoye & $0.16 \mathrm{c}$ & $1.44 \mathrm{~cd}$ & $0.37 \mathrm{bc}$ \\
Jewel & $0.45 \mathrm{bc}$ & $2.46 \mathrm{bc}$ & $0.17 \mathrm{bc}$ \\
Kent & $0.40 \mathrm{bc}$ & $3.06 \mathrm{~b}$ & $0.97 \mathrm{a}$ \\
Mesabi & $0.68 \mathrm{~b}$ & $7.49 \mathrm{a}$ & $2.73 \mathrm{a}$ \\
Mira & $0.16 \mathrm{c}$ & $2.39 \mathrm{bc}$ & $0.90 \mathrm{~b}$ \\
Northeaster & $0.06 \mathrm{c}$ & $0.33 \mathrm{e}$ & $0.03 \mathrm{c}$ \\
Winona & $0.41 \mathrm{bc}$ & $3.66 \mathrm{~b}$ & $0.08 \mathrm{bc}$ \\
\hline
\end{tabular}

${ }^{\mathrm{z}} 1$ ton $/$ acre $=2.2417 \mathrm{Mg} \cdot \mathrm{ha}^{-1} ;$ mean separation within columns by least significant difference at $P \leq 0.05$.
Over the course of this study, the most reliable yielding cultivars were 'Cavendish' and 'Mesabi' in spite of spring frosts that damaged blossoms. 'Mesabi' yielded better than other cultivars during 2002 when plants were frozen in the spring. Only 'Mesabi' yielded above 6 tons/acre (2001) during the course of the study, indicating that it may have potential for limited commercial production in southern Idaho with direct marketing prices (U-pick, farmers' market).

Spring freezing is a limiting factor in strawberry production in southern Idaho. Strawberry plants overwinter well with a straw mulch and snow cover. However, care must be taken not to remove straw mulch too early in the spring and to cover plants with floating row cover when temperatures are $32^{\circ} \mathrm{F}$ or lower.

In 2000, all cultivars except 'Allstar', 'Honeoye', and 'Northeaster' had an average berry weight $5 \mathrm{~g}$ or greater (Table 3). In 2001 all cultivars had berries $5 \mathrm{~g}$ or greater in weight. Largest berries were found in 'Cavendish' ( $8.8 \mathrm{~g})$ and 'Winona' ( $8.5 \mathrm{~g})$. This compares to 15.2 and $13.7 \mathrm{~g}$ in fruit found in 'Cavendish' and 'Winona', respectively, in cultivar trials at the University of Minnesota in 2002 (D.K. Wildung, unpublished data). Average berry weight was extremely variable between replications within each cultivar in 2002 and no significant differences could be determined. In all years, average berry weight decreased as the season progressed by varying degrees depending on cultivar (data not shown). Berry weight in strawberries grown in this trial was smaller than for that found in similar growing

Table 3. The 2000-02 average berry weights of nine strawberry cultivars in a Ketchum, Idaho, planting established in May 1999.

\begin{tabular}{llll}
\hline & \multicolumn{3}{c}{ Avg berry wt $(\mathbf{g})^{\mathrm{z}}$} \\
\cline { 2 - 4 } Cultivar & $\mathbf{2 0 0 0}$ & $\mathbf{2 0 0 1}$ & $\mathbf{2 0 0 2}$ \\
\hline Allstar & $3.7 \mathrm{~b}$ & $5.3 \mathrm{c}$ & $4.7 \mathrm{a}$ \\
Cavendish & $6.5 \mathrm{ab}$ & $8.8 \mathrm{a}$ & $5.6 \mathrm{a}$ \\
Honeoye & $4.2 \mathrm{ab}$ & $5.9 \mathrm{bc}$ & $4.3 \mathrm{a}$ \\
Jewel & $7.1 \mathrm{a}$ & $6.9 \mathrm{abc}$ & $5.2 \mathrm{a}$ \\
Kent & $6.8 \mathrm{ab}$ & $5.7 \mathrm{bc}$ & $4.7 \mathrm{a}$ \\
Mesabi & $6.0 \mathrm{ab}$ & $7.3 \mathrm{ab}$ & $6.4 \mathrm{a}$ \\
Mira & $5.3 \mathrm{ab}$ & $5.3 \mathrm{c}$ & $5.3 \mathrm{a}$ \\
Northeaster & $4.5 \mathrm{ab}$ & $5.5 \mathrm{bc}$ & $4.6 \mathrm{a}$ \\
Winona & $6.3 \mathrm{ab}$ & $8.5 \mathrm{ab}$ & $5.3 \mathrm{a}$ \\
\hline
\end{tabular}

${ }^{{ }^{2}} 1 \mathrm{~g}=0.0353 \mathrm{oz}$; mean separation within columns by least significant difference at $P \leq 0.05$. conditions, and may not be acceptable to local consumers or competitive with fruit from other producing areas.

Midpoints of harvest varied with year (Table 4). 'Winona' had a late midpoint of harvest in all years. Harvest intervals (5\% to $95 \%$ of fruit harvested) for all cultivars fell between 24 June and 5 Aug. in all years (data not shown).

2000-02 RASPBERRIES. In 2000, strong primocanes grew (Table 5.) and by the end of the season, the plants had filled the bed to $2 \mathrm{ft}$ wide. Shoots emerging beyond the 2 - $\mathrm{ft}$-wide row required control through rotovation and digging.

Plant vigor was evaluated each spring (Table 5). All cultivars except 'Lauren' exhibited strong vigor each spring. Tips of the raspberry canes stuck out above the snow in the winter. Each spring, 'Lauren' plants were small and sparse and suffered cold damage to cane tips. 'Algonquin' established slowly, but grew stronger each year. All other cultivars grew quickly and suffered no winter tip freezing. In 2002 lower cane laterals were dead on the portion of the cane that had been under the snow in 'Qualicum' and 'Reveille'.

Spring freezes occurred in May and June each year. In 2001, the first year of production, few flowers were open during freezes on 13 June at 31 ${ }^{\circ} \mathrm{F}$ and 14 June at $30^{\circ} \mathrm{F}$ and no freeze damage occurred. In 2002, some flowers were open on 19 June with $32^{\circ} \mathrm{F}$, and slight flower damage was observed. Raspberries bloom after most of the spring frosts experienced in southern Idaho, so fruiting performance is more reliable than earlier-flowering small fruits.

Table 4. The 2000-02 midpoint of harvests of nine strawberry cultivars in a Ketchum, Idaho, planting established in May 1999.

\begin{tabular}{lrrr}
\hline & \multicolumn{3}{c}{ Midpoint of harvest } \\
\cline { 2 - 4 } Cultivar & 2000 & 2001 & 2002 \\
\hline Allstar & 11 July & 16 July & 8 July \\
Cavendish & 3 July & 15 July & 13 July \\
Honeoye & 16 July & 13 July & 4 July \\
Jewel & 11 July & 17 July & 15 July \\
Kent & 11 July & 10 July & 10 July \\
Mesabi & 4 July & 14 July & 8 July \\
Mira & 10 July & 13 July & 12 July \\
Northeaster & 12 July & 12 July & 2 July \\
Winona & 15 July & 22 July & 20 July \\
\hline
\end{tabular}


Table 5. The 2000-02 average spring plant vigor ratings and fall primocane height measurements of six raspberry cultivars in a Ketchum, Idaho, planting established in May 1999.

\begin{tabular}{|c|c|c|c|c|c|c|c|}
\hline \multirow[b]{2}{*}{ Cultivar } & \multicolumn{4}{|c|}{ Avg spring vigor ${ }^{\mathrm{Z}}$} & \multicolumn{3}{|c|}{ Fall primocane height $(\mathrm{cm})^{y}$} \\
\hline & 15 May 2000 & 30 May 2001 & 31 May 2002 & 3-yr avg & 30 Aug. 2000 & 30 Aug. 2001 & 4 Oct. 2002 \\
\hline Algonquin & 4.3 & 5.3 & 6.0 & 5.2 & 95 & 125 & 152 \\
\hline Lauren & 3.0 & 3.7 & 4.7 & 3.8 & 126 & 135 & 175 \\
\hline Nova & 5.0 & 6.7 & 6.0 & 5.9 & 119 & 144 & 163 \\
\hline Qualicum & 6.0 & 5.0 & 5.7 & 5.6 & 135 & 154 & 155 \\
\hline
\end{tabular}

${ }^{2}$ Vigor scale: $1=$ barely alive; 5 = weak, but acceptable, growth; $10=$ growing extremely well.

${ }^{y} 1 \mathrm{~cm}=0.3937$ inch.

No harvest was done in 2000 due to the loss of floricanes to mule deer feeding. In subsequent years, raspberry fruit were harvested weekly from late July through early to mid-September (26 July through 13 Sept. 2001 and 23 July through 10 Sept. 2002). In 2001 , 'Nova' produced economically viable yields at 7.7 tons/acre, as did all raspberry cultivars in 2002 except for 'Lauren' (Table 6). 'Nova' yielded best in 2001, but other cultivars except 'Lauren' were not significantly different in yield by the second harvest year. The winter kill to lower laterals in 'Qualicum' and 'Reveille' did not appear to affect yield greatly. The 2001 yields at the North Central Research and Outreach Center (Grand Rapids, Minn.) of 'Nova' and 'K-81-6' were lower with 3.8 and 0.18 ton/acre, respectively (D.K. Wildung, unpublished data).

The average berry weight of 'K-81-6' was significantly larger in both years than for all other cultivars except for 'Qualicum' in 2001 (Table $6)$. Average berry weight decreased by varying degrees in all cultivars as the season progressed in 2001, and in 2002 weight was heaviest mid-season (data not shown). Average berry weight was only slightly heavier at the North Central Research and Outreach Center (D.K. Wildung, unpublished data).

Early-fruiting cultivars in 2001 were 'Nova' and 'Reveille' (Table 7 ). In 2002 'Nova' and 'Reveille' were again early; 'Algonquin' was intermediate; and the other cultivars were late. Harvest intervals were similar in all cultivars for each year (Table 7).

Over the course of this study, the

Table 6. The 2001-02 yields and average berry weights of six raspberry cultivars in a Ketchum, Idaho, planting established in May 1999.

\begin{tabular}{llrlll}
\hline & \multicolumn{2}{l}{ Yield (tons $/$ acre $)^{\mathrm{z}}$} & & \multicolumn{2}{c}{ Avg berry weight $(\mathbf{g})^{\mathrm{z}}$} \\
\cline { 2 - 3 } \cline { 5 - 6 } Cultivar & $\mathbf{2 0 0 1}$ & $\mathbf{2 0 0 2}$ & & $\mathbf{2 0 0 1}$ & $\mathbf{2 0 0 2}$ \\
\hline Algonquin & $2.2 \mathrm{bc}$ & $8.2 \mathrm{a}$ & & $1.8 \mathrm{c}$ & $1.5 \mathrm{c}$ \\
K-81-6 & $3.7 \mathrm{bc}$ & $10.4 \mathrm{a}$ & & $3.3 \mathrm{a}$ & $2.5 \mathrm{a}$ \\
Lauren & $1.5 \mathrm{c}$ & $3.8 \mathrm{~b}$ & & $1.9 \mathrm{bc}$ & $2.1 \mathrm{~b}$ \\
Nova & $7.7 \mathrm{a}$ & $7.5 \mathrm{ab}$ & & $2.1 \mathrm{bc}$ & $1.7 \mathrm{~b}$ \\
Qualicum & $3.0 \mathrm{bc}$ & $7.4 \mathrm{ab}$ & & $2.3 \mathrm{ab}$ & $2.1 \mathrm{~b}$ \\
Reveille & $5.6 \mathrm{ab}$ & $5.6 \mathrm{ab}$ & & $2.0 \mathrm{bc}$ & $1.9 \mathrm{~b}$ \\
\hline
\end{tabular}

${ }^{2} 1$ ton $/$ acre $=2.2417 \mathrm{Mg} \cdot \mathrm{ha}^{-1} ; \mathrm{lg}=0.0353 \mathrm{oz} ;$ mean separation within columns by least significant difference at $P \leq 0.05$.

Table 7. The 2001-02 midpoint of harvests and harvest intervals of six raspberry cultivars in a Ketchum, Idaho, planting established in May 1999.

\begin{tabular}{lcrlrc}
\hline & \multicolumn{2}{c}{ Midpoint of harvest } & & \multicolumn{2}{c}{ Harvest interval (5\% to 95\%) } \\
\cline { 2 - 3 } \cline { 6 - 7 } Cultivar & $\mathbf{2 0 0 1}$ & $\mathbf{2 0 0 2}$ & & $\mathbf{2 0 0 1}$ & $\mathbf{2 0 0 2}$ \\
\hline Algonquin & 14 Aug. & 8 Aug. & & 2 Aug.-27 Aug. & 25 July-24 Aug. \\
K-81-6 & 15 Aug. & 15 Aug. & & 2 Aug.-2 Sept. & 27 July-27 Aug. \\
Lauren & 10 Aug. & 17 Aug. & & 26 July-24 Aug. & 24 July-24 Aug. \\
Nova & 6 Aug. & 5 Aug. & & 25 July-22 Aug. & 23 July-20 Aug. \\
Qualicum & 19 Aug. & 12 Aug. & & 15 Aug.-3 Sept. & 28 July-30 Aug. \\
Reveille & 3 Aug. & 31 July & & 24 July-19 Aug. & 23 July-17 Aug. \\
\hline
\end{tabular}

best yielding cultivar was 'Nova', which established well and yielded most during the first year of harvest. All other cultivars except 'Lauren' yielded as well as 'Nova' in the second year. 'K-81-6' had the heaviest berries. All cultivars except 'Lauren' have the potential to be commercial cultivars in southern Idaho. By the second year, all cultivars were yielding well above the break-even yield of 3 tons/acre. Raspberries bloom after most spring frosts, making them suitable for southern Idaho production, and in this study all but 'Lauren' had winter-hardy canes.

\section{Literature cited}

Cross, T. and B.C. Strik. 1991. Enterprise budget, strawberries, Willamette Valley region. Oregon State Univ. EM 8463.

Strik, B.C. 2002. Growing strawberries in your home garden. Oregon State Univ. EC 1307.

Turner, B., T. Cross, B. Strik, and D. Kaufmann. 1993. Enterprise budget, red raspberry, Willamette Valley region. Oregon State Univ. EM 8539. 